\title{
Children's agency and its contradictions in the context of transnational labour migration from Vietnam
}

\author{
LAN ANH HOANG ${ }^{*}$ AND BRENDA S. A. YEOH ${ }^{\dagger}$ \\ *(corresponding author) School of Social and Political Sciences, \\ The University of Melbourne, Melbourne, Victoria 3010, Australia \\ lahoang@unimelb.edu.au \\ ${ }^{\dagger}$ Asia Research Institute and Department of Geography, \\ National University of Singapore, AS2/04-16, \\ 1 Arts Link, Kent Ridge, Singapore 117570 \\ geoysa@nus.edu.sg
}

\begin{abstract}
In this article, we contribute to the growing and diverse literature on the lived experiences of children and their agency in the context of migration. Drawing on in-depth interviews with children whose migrant parents have left them behind, as well as with those who care for them in Vietnam, we demonstrate that the various ways in which they affect migration decision-making and transnational communication shape the children's imaginations of migration. The context-specific social construction of childhood, or more specifically adult perceptions of children's agency and needs, in turn structures these processes. We emphasize the need for debates on children's agency to take into account both broader socio-economic processes at the macro level and the concrete and local scale at which children's lives unfold. By outlining how children's experiences of parental migration are constitutive of their attitudes toward this livelihood strategy, we also argue that the ability of those 'leftbehind' to exercise agency is closely intertwined with processes of social becoming and navigation in the transnational social fields constructed for them by adults.
\end{abstract}

Keywords TRANSNATIONAL MIGRATION, LEFT-BEHIND CHILDREN, CHILDHOOD, AGENCY, VIETNAM

For our study we drew on a research project named CHAMPSEA (Child Health and Migrant Parents in Southeast Asia), which examines the effects of parents' transnational labour migration on the health and well-being of children in four Southeast

(C) 2014 The Authors.

Global Networks published by Global Networks Partnership and John Wiley \& Sons Ltd.

This is an open access article under the terms of the Creative Commons Attribution License, which permits use, distribution and reproduction in any medium, provided the original work is properly cited. 1 
Asian countries - Indonesia, the Philippines, Thailand and Vietnam. The idea for this article, however, came from personal childhood recollections that kept resurfacing during the two fieldwork trips that Lan (the first author) made in 2009 and 2011 to conduct in-depth interviews with left-behind members of transnational families in Thai Binh Province, Vietnam. In 1982, Lan's own father had left his family behind in Vietnam when he went to join hundreds of thousands of Vietnamese contract workers heading for factories and construction sites in the former Soviet Union. The only means of communication at that time was by letter, sent by post or carried by visiting friends and colleagues, and these letters usually took months to reach their destination. Lan clearly recalls the letter-writing 'ritual' of her childhood when, bent over a bamboo mat, she and her sister would carefully and neatly inscribe words of love, as dictated by their mother, on Soviet-made paper to be sent to her father. Lan's mother composed practically all the letters, and they were almost always identical. In hindsight, it was clear that Lan's parents worked as a team to keep their children oblivious of the agony, anxiety, frustration and hardship resulting from the prolonged physical separation and gaps of communication during that period.

During her period in the field for the CHAMPSEA study, apart from the considerable advances in transnational communication, Lan tended to see history repeated among the transnational families she visited. Nowadays, Vietnamese transnational families have relatively easy access to modern information and communication technologies (ICTs) such as telephones and the internet - the so-called 'social glue of migrant transnationalism' (Vertovec 2004) - which allows them to keep in regular contact at a relatively low cost. The seemingly unfettered ability to communicate is a much celebrated feature of contemporary transnational migration, leading some scholars to develop notions of 'absent presence' (Pertierra 2006) and 'co-presence' (Baldassar 2008) ${ }^{1}$ respectively. This implies that ICTs can eliminate the sense of physical separation, a position that more recent studies, including ours (Hoang and Yeoh 2012), have nevertheless challenged.

What resonated with Lan's childhood experience was the way children are positioned in parental migration processes, particularly during the decision-making stage and in transnational communication. We consistently observed the constrained agency of children in the migration of their parents among the families involved in our research. This, as we demonstrate later in this article, has important implications for the sustenance of emotional bonds between migrants and their children and the way they make sense of migration and the outer world. Through our case study of Vietnamese left-behind children, we seek to engage critically with the scholarship on children's geographies, particularly those concerned with the question of children's agency and its contradictions. This is in part a response to Dobson's (2009) call for more research on children's experiences and perceptions of migration, for migration research has largely ignored or muted their voices.

In what follows, we first examine how migration scholars have conceptualized children's agency before reviewing the literature on the children whom migrant parents have left behind. After a short outline of our methodology and research, we then look into the various ways in which Vietnamese children exercise their agency in 
migration decision making and transnational communication amid the constraints of both the context-specific construction of childhood and of global migration regimes. The latter have important implications on how children view migration and the ways they act upon their world (Ansell 2009: 201; Sanders 2001: 28), which, in the particular context of this study, concerns the construction of their immobility or mobility aspirations. In exploring immobile children's conceptions of mobility, we also speak to the new mobility paradigm outlined by Sheller and Urry (2006: 211) in which both sedentary and nomadic accounts matter.

\section{Children's agency in the context of migration}

The question of children's agency only recently started to capture the attention of migration scholars. The conventional perception in migration studies of children as the (often-male) migrant's dependants, 'luggage' or 'things transported by adults' (see Dobson 2009; Ní Laoire et al. 2010; Orellana et al. 2001) has shifted. In childhood studies there has been a reconceptualization of the child as a social actor in his or her own right rather than just an 'adult in making' (cf. James and Prout 1997; James et al. 1998; Jenks 1996). There is ample empirical evidence to suggest that children in contemporary societies do not always cooperate with the view of them as innocent, dependent, incompetent beings needing guidance and protection (Katz 2004; O'Connell Davidson 2005; Uprichard 2008). Although tensions remain in debates about whether we should see children as 'human beings' or 'human becomings', there seems to be a consensus in empirical research about the reality of children's active engagements in everyday negotiations of both being and becoming.

It is important to recognize that children's agency is contingent on a social construction of childhood that is neither static nor universally uniform. Migration scholars in a diverse range of contexts have consistently pointed out that the capacity of children for autonomous action varies with age and that different cultures treat children of the same age differently. For example, in parts of West Africa, South Asia and Latin America, with education not necessarily implicated in the construction of childhood, people regard children around the age of 12 as active economic actors (Iversen 2002; Nieuwenhuys 1994; Punch 2002; Whitehead et al. 2007). Likewise, Matilac and Florendo (2002) suggest that people in some Southeast Asian contexts bring up children to accept their roles as 'income generating members of the family'. The Vietnamese, however, differ, for they invariably see education as central to childhood and stigmatize children's participation in paid work as a social evil (Ennew et al. 2005). The dissimilar positioning of children in different contexts relates directly to the multiplicity of their lived experiences.

The emphasis on children's agency has led to the emergence of a range of methodologies that place children at the core of scholarly enquiry. Research into their perspectives on migration and mobility has generated fascinating accounts of how children actively engage in the decisions that concern their lives. A special issue of Childhood edited by Ní Laoire et al. (2010) is the latest major work on the various ways in which children negotiate and construe home and belonging. Their autonomy 
and independence are particularly salient when they migrate by themselves - they initiate their own migration, sometimes in the face of family opposition, and form their own mechanisms of support and security while living away from home (Beazley 2000; Camacho 1999; Iversen 2002; Punch 2007; Whitehead et al. 2007). Even when children migrate with their families and adults appear to be in charge of the decisionmaking, they may actually shape the nature and course of the families' migration experiences (Orellana et al. 2001: 587).

While children are clearly capable of autonomous action, Ansell (2009) urges us to recognize the limits in their perceptions of space and action. Children do not always have the same access as adults to technology, or indeed the interpretive repertoire or sufficient social status to allow them to act on the world with a similar degree of consciousness and intent. 'Child-centred' studies have been criticized for emphasizing agency over structure, the concrete over the abstract and the local over the global (Ansell 2009: 194). Confining research to a 'local' context would obscure important larger-scale structures and phenomena, such as the globalization that shapes the everyday lives of all children. It is thus important to situate their accounts within broader contexts and to recognize that macro-level socio-economic structures have significant bearings on their agency and relationships with other people.

We should note that most of the discussion in migration scholarship about children's agency concerns migrant children. What remains largely unexplored is how non-migrant children exercise agency in the migration of others, especially their parents. We should be mindful not to allow what are often uncritical celebrations of migrant children's agency to mislead us when we turn our attention to those immobile children whom the migrant parents have left behind. Dreby (2007: 1051) suggests that in Mexico they tend to exert little influence over their parents' initial migration decision, even though they may be able to shape the family's subsequent migration trajectories. In Asia, where transnational labour migration has been increasing exponentially since the 1970s, many questions about children's agency remain unanswered. This is the research lacuna we seek to address in this article.

\section{Children and the experience of being 'left-behind'}

Children are a heterogeneous group, so do not experience separation from their parents uniformly, not least because of changes resulting from their growing maturity and psychological development during the migration process (Carling et al. 2012: 206). The literature on Latin America and Asia has provided intriguing accounts of the emotional ramifications of family separation (Dreby 2010; Parreñas 2001, 2008; Schmalzbauer 2004), the commodification of parent-child relationships (Artico 2003; Moran-Taylor 2008) and family conflict upon reunification (Artico 2003; Menjivar 2000). In particular, children tend to experience more intense psychological stress when their mothers migrate (Dreby 2010: 80) but the emotional gap is likely to be greater between them and their migrant fathers (Parreñas 2008; Pribilsky 2004). However, in places where there is a 'culture of migration', as in the Philippines (Parreñas 2005a) or the Caribbean (Olwig 1999), neither children nor adults 
necessarily see parent-child separation as traumatic. Regular transnational communication, as well support from the extended family, might offset the emotional ramifications on the children, particularly when their mothers are away (Hoang and Yeoh 2012; Hoang et al. forthcoming; Parreñas 2005a).

With increasingly restrictive migration policies in receiving countries worldwide keeping migrant families separated longer and family reunification more difficult (Carling et al. 2012: 199), transnational communication has become the most important channel of engagement and bonding for separated family members (Dreby 2006; Hoang and Yeoh 2012; Parreñas 2001; Schmalzbauer 2004). Communication allows migrant parents and their children to exchange information and it serves to affirm the social meaning of long-distance relationships. However, research has demonstrated that access to ICTs is not uniform across contexts and the inability to stay in touch regularly might generate imperfections and gaps of information, often to the detriment of family relationships (Carling 2008; Hoang and Yeoh 2012; Mahler 2001). Honduran children in Schmalzbauer's (2008: 339) study, for example, have little knowledge of their migrant parents' lives and often assume that they are doing well while in reality their parents are struggling, partly because parents 'relativize' their communication with family back home.

An important determinant of how children experience separation is age. Transnational ties are particularly fragile when children are very young at the point of a parent's departure and they may have no real memories of them (Schmalzbauer 2004: 1324). Dreby (2010: 116), however, observed that young Mexican children in her study did not seem to experience as much distress as teenagers did. Children who are older at the time of a parent's migration often have stronger memories of a time when they lived together and thus tend to have a keener sense of separation and to exhibit a stronger desire for emotional connections with their parents (Carling et al. 2012: 207). Migrant parents find it difficult to appreciate the changes that occur in children's thinking and emotions while they are growing up during their absence and this complicates the situation. Although regular communication may help parents maintain a virtual presence in the family home, it does not always provide the intimacy usually attained through day-to-day physical interactions (Hoang and Yeoh 2012). As separation continues, migrants and their children increasingly draw on secondary sources of information for the construction of migration and places. These include the media, gossip, hearsay and their own imaginations.

\section{Research methods and context}

In this article, we draw on the qualitative research component of the larger CHAMPSEA study $^{2}$ we conducted in Thai Binh Province, in Vietnam, from 2009 to 2012. In 2009, we interviewed the carers of 37 left-behind children, of whom eighteen were fathers, eleven mothers, seven grandmothers and one a grandfather. The main aim of these interviews was to explore care arrangements for left-behind children and the webs of relationships around them. In December 2011 and January 2012, we conducted in-depth interviews with fathers in 44 mother-migrant households, 
more than half of whom $(n=24)$ had been surveyed in 2008. The main aim of the 2011-12 study was to understand how female migration affected the gender identities and sexualities of both 'left-behind' husbands and migrant wives. ${ }^{3}$ We also took this opportunity to explore further some issues that the 2009 study raised relating to the effects of female migration on children. We therefore interviewed 15 children (eight boys and seven girls) aged between 12 and 15 from the participating households.

Various studies have shown that children are potentially vulnerable to exploitation by adult researchers and that the damage is not necessarily limited to face-to-face interactions; it extends also to the interpretation and presentation of the findings (Lansdown 1994; Morrow 2008). We thus took ethical considerations seriously in the design and conduct of our child interviews. We mediated access to the children via their interviewed fathers and obtained informed consent from both of them. One of us (Lan, a Vietnamese woman in her mid-thirties) interviewed the fathers and children separately in Vietnamese on a one-to-one basis. We treated the information exchanged in the interviews as confidential; we did not divulge it to the fathers and children involved, or to any other family members. All the interviewed children had participated in the 2008 survey and had met Lan in 2009, so a rapport with them was quickly re-established. It was particularly important that she came from the same province, for it helped narrow the social distance between them and enabled her to gain their trust. Two of the 15 children became upset during the interview, so she terminated it prematurely to offer them emotional support. The rest responded positively to the interview questions.

Following the collapse of the communist regimes in the former Soviet Union and Eastern Europe, Vietnam started to export labour to non-socialist destinations for the first time in the early 1990s. By 2008, more than 500,000 Vietnamese migrants were working abroad (Dang et al. 2010: 12), with nearly 76,000 deployed overseas via regular channels in 2010, mostly to Taiwan, Malaysia, South Korea and the Middle East. ${ }^{4}$ Labour migration from Vietnam remains male-dominated; women accounted for 30.1 per cent in 2009. Men mostly work in the construction, farming, seafaring and manufacturing sectors, while women mostly work in domestic and care services, as well as manufacturing. Thai Binh - our study site - is a coastal province $110 \mathrm{~km}$ southeast of Hanoi. It deployed 2410 workers overseas in 2010, pushing the total number of overseas migrant workers from the province to over $20,000 .^{5}$

\section{Children in migration decision-making processes}

Every single carer and 'left-behind' husband in our study mentioned children in their accounts of migration decision-making, though not in the capacity of decision maker. They frequently explained the decision to migrate or return, made almost exclusively by the parents, in terms of the children's best interests. Children's voices were largely absent during the decision-making process. Most of them only learnt about their parent's imminent departure shortly before they left. In her interview on 13 December 2011, 11-year-old $\mathrm{Kim}^{6}$ wept as she said 'my dad was the first person to tell me that mum was going to Taiwan. It was hours before her departure.' 
For various reasons, the migrating parent was rarely the one to break the news to the children which, together with the fact that children were often informed at the last minute, appeared to have contributed to the distress they still felt keenly during our interviews, years after the event. Twice we had to end the interview halfway through because recalling the mother's departure was too upsetting for the child in question. The adults tended to explain their lack of communication with their children in terms of the limited time between the recruitment interview and departure. Although it was true that some migrants in our research had to leave Vietnam as soon as their deployment was confirmed (usually following an interview with the agency representing Taiwanese employers), the whole application process involving medical tests and paperwork took months. In fact, most of the parents we interviewed felt no need to discuss their plan with their children because they believed children could not comprehend the complicated issues involved and doing so would only create unnecessary trouble. In his interview on 27 April 2009, Thanh, a 46-year-old farmer, smiled as he explained 'it is us as their parents who make the decision. They are just kids and they all would say the same thing when they have to be separated from their mom.'

The absence of children's voices in migration decision making is, nevertheless, not unique to our Vietnam study, for a similar observation has been made in other contexts (see Dreby 2007; Orellana et al. 2001). What makes the Vietnamese one different is the considerable extent to which adults tell white lies to comfort their children at the point of the migrant parent's departure. One-third of the children interviewed in late 2011 said that their carers lied to them about their parent's absence; in fact, seven of the 37 carers we visited in 2009 reported lying to or concealing information from children when their parents left the country. The age of a child at the point of a parent's departure appeared to be a key factor differentiating their experiences of parental migration, with preschool children less likely to hear the truth. Below was how Su, a 58-year-old grandmother carer (interviewed on 26 May 2009) recalled the time when her daughter-in-law left her three-year-old daughter behind to migrate to Malaysia:

She missed her mum so much when her mum just left. Sometimes she cried asking for her mum and I lied to her that her mother had gone to work and would be home in the evening. In the evening she asked me when her mother would be home, I told her that her mother would be home the next day. Now she is older and knows that her mother works far away from home. She keeps asking me when her mother will be home and I lie to her that her mother will be home at the end of the year.

Yen, a 34-year-old mother (interviewed on 28 May 2009) echoed Su's story when she described how her five-year-old son learnt about his father's migration to Brunei:

I first lied to him that his father had gone to work in a company and would be home for dinner. When the boy did not see his father at dinnertime, he asked me again why it took his father so long to get home. I lied again that his father 
had to do a night shift. He realized later that I had been lying to him, saying that he knew his father had gone away to work.

Carers employed the lie-telling strategy not only at the point of the parent's departure but also throughout the migration process. Migrant parents frequently asked their stay-at-home spouses to buy gifts for their children on their behalf and to tell them that the former had sent them from their overseas locations. In one case, a 12 year-old boy, Quang, told us that he had been unable to communicate with his mother for months because she somehow only phoned his father late at night while he was sleeping. Quang's mother actually had been missing for six months after working for five years in a nursing home in Taiwan. Van, Quang's father, was extremely upset about this and in a separate interview (on 16 December 2011) said:

She used to phone home regularly, but since the kids' new school year started [in September] she has not contacted me. I tried to ring her mobile number but only heard someone speak Chinese. It might be an operator. ... Sometimes the kids wonder why their mum has not rung them for a long time. I do not want to tell them because they are too young. I am afraid it would affect their studies if they find out.

Although Van had been trying to hide his distress from his children, it did not go completely unnoticed. 'He [Van] cries every time someone asks about her,' Quang remarked. $^{7}$ That children were often lied to about their parents' migration did not come as a surprise because telling children white lies is not necessarily regarded as bad practice in Vietnamese culture. This appears to be rooted in the Vietnamese construction of children as 'inert' people incapable of comprehending adult affairs (chuyện ngườ lón) and at the same time needing protection. The adults involved in our study looked upon lying as an effective way of protecting children from the trauma of separation. Psychological studies in Western contexts echo this finding in that they suggest that parents see prosocial (white) lies as acceptable and preferable to the truth if they protect someone's feelings (Eisenberg et al. 1995). Children are supposed to be 'protected' from harsh environments and complicated issues (Trask 2010). However, white lies might not be completely harmless because there is evidence to suggest that children exposed to them become more frequent and proficient prosocial liars. Children who understand the cues to deception, McCarthy and Lee (2009) suggest, might be able to manipulate these cues to lie successfully.

This is not to say children were wholly passive with regard to parental migration. A number of them put up resistance to their parent's imminent departure, begging them to stay or asking someone else in the family to intervene so that the migrant would change his or her mind. All but one case involving some form of resistance concerned the migration of the mother - a fact that suggests there might have been greater tension and distress among children of migrant mothers. There was also a sense of resignation among older girls about the economic imperative of transnational labour migration: 'Mom told me she was leaving just before her departure. I knew it 
was only because of us ... we needed money for education ... so I let her go' (Thanh, a 15-year-old girl, interviewed on 20 December 2011).

Like Thanh, Nga, who was also 15 years old at the time of the interview, ${ }^{8}$ said that although she was sad that her mother was leaving, she did not say anything to her because 'it's up to my parents and not me.' Nevertheless, the reluctant acceptance of the physical separation from their mothers does not mean that it does not disturb the children. Many became emotional when recalling the moment of departure. Although children's reactions to parental migration did not seem to be gender specific (see also Hoang and Yeoh 2012), the interviews suggest that girls tended to be more thoughtful about the separation than were their male peers in the same age range (12-15 years). They made more effort to understand their parents' migration decision and seemed to be more sympathetic to such an arrangement.

\section{Children at the receiving end of transnational communication}

Migrants' usually greater efforts in transnational communication compared with those staying behind, Carling (2008: 1457) explains, are due to the intrinsic asymmetries in the 'moralities of transnationalism' that place a heavier burden on them to maintain and nourish transnational relationships. Nevertheless, this pressure is often at odds with the everyday reality of low-waged migrant workers' lives at the destination. The narratives in our study about transnational communication reveal interesting details about the structural embeddedness of migration in the global economic order. Most mother migrants in our study engaged in domestic or care work in private households or nursing homes in Taiwan. Such highly circumscribed work did not always allow them to choose the time and means of communication to suit the daily routine of their children back home. As Kho, a 12-year-old boy interviewed on 15 December 2012 explained, 'sometimes I ring my mum but she told me not to let the phone ring long, just enough for her to know (so that she would call back later). She would be fired straight away if caught using the phone at work.'

A number of migrant parents had 'run away' from their contracted jobs and, fearing that the local authorities might track them down, had no regular mobile phone number attached to them. Such factors, coupled with the excessive telecommunication charges relative to income in Vietnam, structured transnational communication into a unidirectional flow that the migrant almost exclusively initiated. Children's passivity in transnational communication was more than just waiting for migrant parents to call; they also let the latter take the lead in phone conversations. As Nga, a 15-yearold girl interviewed on 18 December 2012 said of her mother, 'she often talks about our family. ... I rarely ask her anything, partly because I am shy. Also, I don't like asking her questions.'

As we have discussed extensively elsewhere (Hoang and Yeoh 2012), the emotional gaps created by long-term physical separation from their migrant parents is largely responsible for the children's passivity in transnational communication. As Leifsen and Tymczuk (2012: 229) noted in their study of Ecuadorian migrants in Madrid, love and care communicated via the phone tend to have limited effects if not 
followed by physical acts. Over time, the calls lose much of their emotional content and turn into routinized and indifferent chores for everyone involved. Parental insensitivity during the communication can inadvertently widen the geographical distance. For many reasons, including limited time and money for phone calls, the need to speak to each individual family member in turn, as well as the lack of awareness of changes in children's expectations and feelings, the migrant parents in our study tried to make their conversations as brief as possible. They tended to focus on the key features of life among those they had left behind rather than allow the latter to get to know about their lives overseas. In an interview on 20 December 2011, Giao, a 15-year-old girl, said 'my mom always asks too many questions so I never ask her back. She asks too much, one thing after another. She asks if I do well at school, how my dad and grandmother are and how well our relatives do, etc.'

Again, age was a major factor in shaping children's communication behaviour. Our interviews in 2009 with carers of children aged between three and five suggest that younger children become more excited when their migrant parents get in touch, even although many of them no longer remembered them (Hoang and Yeoh 2012: 321). This was largely due to carers' constant efforts to remind children of their parents, aided by material gifts from overseas or the anticipation of such. Given that most mothers in our study left Vietnam for the first time in 2004 or later, the adolescent children interviewed in 2011 and 2012 had developed an emotional bond with their mothers prior to separation. They seemed to expect more from transnational communication and were more sensitive to the quality of the conversation. The repetitiveness of phone conversations (focused on life 'back home') and the children's lack of ability to engage in their migrant mothers' lives 'over there' gradually fomented a sense of detachment and aloofness among the youths.

The migrant mothers' efforts to discipline their adolescent children from afar appeared to exacerbate the growing emotional distance between them. Whereas mothers in the Philippines (Parreñas 2001; Parreñas 2008), Mexico (Dreby 2006) and Honduras (Schmalzbauer 2004) strive to maintain loving, caring relationships with their children and largely leave the disciplining to the distant fathers, in Vietnam, mothers are the major disciplinarian figures in transnational relationships. Concerned about their children's behaviour and school performance, the mothers made sure that every hard-earned dollar they spent on transnational phone calls would help to allay their worries about them going astray in their absence. Enquiries about the children's marks at school, crosschecking different sources of information, scolding and yelling were common features of transnational conversations. Many of the children, especially when they reached adolescence, began to find the disciplinary sessions over the phone a burden and so they gradually lost interest. Boys were more likely to be the victims of scolding and, as a result, tended to be less comfortable with transnational communication. In an interview on 27 May 2009, Doan, the 38-year-old father of ten-year-old Thuong said:

He just responds to his mum's questions. He talks, but not much. ... He is still a young boy so he is afraid of being scolded if she knows that he plays a lot 
outside the house. We have to yell at him all the time. He would be spoilt if we were just sweet to him.

A 13-year old boy called Hanh (interviewed on 19 December 2012) said of his mother, 'I don't know what she does over there. ... When she calls, she always says, "come on, work harder, slacker!" I never ask her anything. She always says she is busy. Only my dad asks her things.'

Doan and Hanh's narratives exemplify the popular Vietnamese approach to child rearing - 'spare the rod, spoil the child' (Yêu cho roi cho vọt, ghét cho ngọt cho bùi) that migrant mothers continue to practise from a distance. The children did not see it as motherly concern and the disjuncture in communication was detrimental to their emotional bonds, already fragile after such a long physical separation and resulting absence of intimacy. The inflexibility in the migrants' performance of their mothering role contributed to the children's retreat into silence each time the former got in touch.

As the above quotes show, while children are at the centre of migration decisionmaking and transnational communication, adults commonly treat them as the passive receivers of attention, love, care and gifts who are incapable of independent thought and action. The phrase 'too young to understand anything' (chúng nó còn bé sao hiểu duo $\left.{ }^{\circ} c\right)^{9}$ surfaced in many interviews when we asked adults about their children's reactions to migration-related events. Many migration scholars have emphasized the importance of regular communication in the maintenance of parent-child emotional bonds (Hoang and Yeoh 2012; Parreñas 2005b; Zentgraf and Chinchilla 2012). The point we wish to add is that the quality and content of the communication are what really matter, for regular yet insensitive communication between parents and children may widen rather than close the emotional gaps created by migration. That adults often overlook children's agency, as shown in what follows, has important impacts on their construction of and feelings about transnational labour migration.

\section{Migration through children's eyes: ventures of hardship and sacrifice}

As we mentioned earlier, transnational phone calls were full of mundane details about day-to-day life back home, with little acknowledgement that migrants had their own lives to lead overseas. Fedyuk (2012: 295) came up with a similar finding about Ukrainian migrant women in Italy. Thus, the Vietnamese children in our study knew very little about their migrant parents' lives or the places in which they were living. For many of them, the overseas abode was simply a land of abundant material possessions and migration would automatically unlock a supply of gifts and money. In an interview on 28 May 2009, five-year-old Tien's father, Tinh, aged 36, said 'kids forget things easily. He only says that his mum will buy him such and such a toy when reminded of her. He does not say he misses her; when she phones, he asks his mum to buy him the toys that he sees at his friends' places.' Asking migrant parents to buy them toys seemed to be the most common message from children. That they associate migration with material abundance is not accidental. Both the carers and the migrant parents actually cultivate it by frequently promising gifts as incentives to 
behave well or work hard at school. As Giang, the 32-year-old mother of an 11-yearold boy Chung explained (interview 6 May 2009), 'I tell the boy: "your dad will buy you something if you do well at school".'

In the 2011 and 2012 interviews, we asked the children what they knew about Taiwan, where their mothers were living at the time. They eagerly and elaborately described the country of their imagination. Taiwan, according to them, was smaller but much richer than Vietnam. It had beautiful cities, big roads, tall skyscrapers and green parks. There are many elderly people in wheelchairs there, as well as 'big' people who drive cars (not motorbikes as in Vietnam), many of whom are 'nasty' and 'talk bad things about Vietnam'. As it turned out, most of the children said they learned about Taiwan from the media, tales told by returned migrants, village gossip and photos their mothers sent home, but not directly from phone conversations because their mothers rarely spoke about their lives overseas. Although the children often imagined the overseas location as a better world, they did not necessarily think that their migrant parents were having a good time away from home. In fact, their migrant parents and carers routinely reminded them of the hardships the migrants had to endure to provide them with a better future. To cultivate a sense of gratitude in children and motivate them to be 'good kids', the adults deliberately constructed a migrant's life as lonely and full of suffering and sacrifice. As Thoa, a 33-year-old mother explained, 'I tell them that their dad has to work very hard abroad so they have to do their best to show their gratitude to him' (interview, 4 May 2009). For this reason, when their migrant parents got in touch, many older children, particularly the girls, chose to divert the conversation away from emotionally charged topics. For example, One 11-year-old girl often talked about her migrant father and wished he were home to take her out during national holidays, but she never communicated her feelings directly to him because she said 'I am afraid I would make him sad.' In an attempt to maintain their affective ties with people in the homeland, migrants frequently and in a number of different contexts deliberately portray their lives overseas in a certain light during their transnational communications and home visits. Salvadorans in Australia (Ramirez et al. 2007: 425) and Ukrainians in Italy (Fedyuk 2012: 294), for example, try hard not to stir up mistrust or jealousy among the relatives they have left behind, or feelings of neglect in their children, by carefully choosing unflattering and simple photos of themselves to send home. Other studies, by contrast, suggest that migrant parents often make conscious efforts to conceal the harsh circumstances of their lives so as not to worry the family back home (Boccagni 2012; Schmalzbauer 2008). Nevertheless, the Vietnamese migrants in our study and their partners at home chose to play up the hardship and self-sacrifice of their migration endeavours. This particular construction of migration in the Vietnamese context, as discussed below, has important implications for children's responses to parental migration and aspirations for their own futures.

Research in the Philippines (Parreñas 2005a) and Mexico (Dreby 2010) tends to highlight children's feelings of abandonment and resentment towards migrant parents, which might be attributable to the context-specific construction of migrant life as one 
connected with wealth, modernity and self-indulgence. Filipina workers in Hong Kong, for example, often send home pictures of themselves smiling and looking happy in fashionable new clothes at fancy shopping centres (Margold 2004). The children we interviewed in Vietnam though did not express any negative feelings towards their migrant parents. Rather, they saw them, as they saw themselves, as powerless people making great sacrifices in the best interests of the family - a finding that resonates with observations by Åkesson et al. (2012) in Cape Verde and Boccagni (2012) of Ecuadorans in Italy. The Vietnamese children saw migration as an undesirable livelihood choice - something they would not want for themselves when they grew up. As one of the girls exclaimed, 'I don't want to go overseas and suffer like my mum! ${ }^{10}$ Only one of the 15 children we interviewed in 2011 and 2012 wanted to migrate overseas for work in the future. This stands in sharp contrast to research in Latin America that identifies migration 'up North' as a common aspiration among youths and children of migrants who often drop out of school early to follow in their parents' footsteps (Artico 2003; Dreby 2010: 140). Studies undertaken in Ghana (Langevang and Gough 2009: 752) and Tanzania (Salazar 2010) also find that youths strongly associate international migration with social mobility.

Not only did the bleak picture that adults painted of transnational labour migration discourage the Vietnamese children in our study from a similar venture in the future, but the emotional costs borne by family members also disheartened them. Ngoc, the 12-year-old girl interviewed on 15 December 2011, said:

What I don't like [about migration] is that my dad often misunderstands my mum. He suspects that she does not want to come back because she has been away for a long time. ... I do not want to go overseas when I grow up. If I get married and my husband is like my dad, he would misunderstand me too.

As Salazar (2010) suggested in his Tanzania study, migration in its broadest sense involves important imaginary and discursive dimensions on the parts of both the migrant and those who remain behind. The children in our study might appear passive and dependent to their parents, but their narratives reveal that they were conscious of what was going on and that they actively navigated the imaginary and real worlds that their parent's migration shaped, if not in word and immediate action, then in fashioning their own aspirations. Children, Ansell (2009: 200) points out, 'make sense' of the world; their experiences are not raw but blend memories, images and feelings. Although the children invariably saw migration as undesirable, they appreciated the self-sacrifices their migrant mothers made to sustain and elevate their quality of life in Vietnam and did not associate their absence with 'bad' mothering. However, it is important to remember that children's reactions to parental migration vary according to age, the length of the parent's absence and the quality of the transnational communication. The care provided by left-behind relatives is also an important factor (Åkesson et al. 2012; Hoang and Yeoh 2012; Parreñas 2005b) and, indeed, responses may change over time (Artico 2003; Dreby 2010; Menjivar 2000). 


\section{Conclusion}

In this article, we have chosen to address our concerns about children's agency in three crucial and interrelated aspects of transnational labour migration. These are migration decision making, transnational communication and children's imaginings of migration and place. An understanding that imagining is a social practice underpins the inclusion of imagination in this research. Arjun Appadurai (1996: 31) argues that the imagination is a form of 'negotiation between sites of agency and globally defined fields of possibility'. The children in our study were keenly aware of the wider socioeconomic constraints that condition their lives and those of their migrant parents, as well as of the transnational social field in which they were partaking. What appeared to adults as passivity and dependence were, in fact, children's active and conscious engagement in meaning making of (and day-to-day negotiations with) the social and economic configurations of transnational labour migration and family relationships. The reluctant resignation of Thanh and Nga towards the separation from their mothers, the seeming aloofness of Nga, Giao and Hanh during transnational communications, and Thuong's routine evasion of his mother's phone calls were all reflective of both their imaginings of parental migration and their responses to it. These remind us that agency is as much about inactivity as activity, which fits with Taylor's (2002) suggestion that the social imaginary is more than just ideas; it enables practices of a society through people making sense of it.

In our discussion of Vietnamese children's agency, we engaged with the voices of both the children and the adults in their lives. This methodological choice allowed us to look at children's agency from different angles and to appreciate not only the subjective accounts of their thoughts, feelings and acts about their parents' migration but also the socio-cultural contexts within which their agency is embedded. Of particular importance is the Vietnamese social construction of the child as a passive receiver of care and protection that compels the children in our research to act in certain ways. Our findings also emphasize that age and gender have important bearings on their agency, partly because of the varying ways adults subject girls and boys of different ages to attempts at 'householding' (Douglass 2006) and 'kinwork' (di Leonardo 1987). These local elements cooperate with larger forces such as the gendered division of labour in the global economy, the restrictive Asian migration regime, and the socio-spatial polarization in transnational communication networks to shape the agency of left-behind children in distinctive ways. As such, the study reinforces Ansell's (2009) view that structures and phenomena at both local and global levels matter in the scholarly consideration of children's agency, especially in the context of transnational migration.

In this study of Vietnamese children left behind by migrant parents, we juxtaposed the spatial immobility of the children with the mobility of their parents in their imagination of transnational labour migration and the foreign place. These sedentary accounts of mobility reaffirm the importance of 'moorings' as much as 'mobilities' (Cresswell 2010: 18; Sheller and Urry 2006: 211) in children's construction of their own immobility or mobility aspirations. Research in various African contexts has 
shown how youths' mobility is embedded in processes of cultural meaning-making and social navigation (Langevang and Gough 2009; Salazar 2010; Vigh 2006). We add further insights into children's processes of social becoming by examining how their immobility intersects the mobility of their parents.

\section{Notes}

1. We discuss these notions in relation to broader social relationships and not specifically those between adults and children.

2. For the quantitative component of the CHAMPSEA study, we surveyed approximately 1000 migrant and non-migrant households in 2008. We filled in structured questionnaires for two or three members of each household - a child (aged between 3 and 5, or 9 and 11), the carer of the child, and a responsible adult in the household (if not the same as the carer).

3. Following the fieldwork in Vietnam in December 2011-January 2012, we travelled to Taiwan in June/July 2012 to interview 30 Vietnamese migrant women, half of whom were married to the men participating in the study. Since we are not using data collected from the Taiwan study in this article, we have excluded these interviews from the discussion of methodology.

4. http://workbank.vn/news-print/2-3508/Chien-luoc-lao-dong.html.

5. http://www.thaibinh.gov.vn/ct/news/Lists/CulturalSocial/View_Detail.aspx?ItemID=4950, accessed on 28 November 2011.

6. We have changed the names of all respondents to protect their privacy.

7. Interview with Quang on 16 December 2011.

8. Interview, 18 December 2011.

9. Interview with Danh, a 36-year-old father of two, 27 May 2009.

10. Interview with Nguyen, aged 15, 17 December 2011.

\section{Acknowledgements}

We are indebted to the research participants who generously shared stories of their lives with us. Our most sincere thanks go to the editors of Global Networks and three anonymous reviewers for their insightful comments on previous versions of this article. The Wellcome Trust, UK (GR079946/B/06/Z and GR079946/Z/06Z) funded the study.

\section{References}

Åkesson, L., J. Carling and H. Drotbohm (2012) 'Mobility, moralities and motherhood: navigating the contingencies of Cape Verdean lives', Journal of Ethnic and Migration Studies, 38 (2), 237-60, doi: 10.1080/1369183X.2012.646420.

Ansell, N. (2009) 'Childhood and the politics of scale: descaling children's geographies?, Progress in Human Geography, 33 (2), 190-209, doi:10.1177/0309132508090980.

Appadurai, A. (1996) Modernity at large: cultural dimensions of globalization, Minneapolis: University of Minnesota Press.

Artico, C. I. (2003) Latino families broken by immigration: the adolescent's perceptions, New York: LFB Scholarly Publishing.

Baldassar, L. (2008) 'Missing kin and longing to be together: emotions and the construction of co-presence in transnational relationships', Journal of Intercultural Studies, 29 (3), 247-66, doi: 10.1080/07256860802169196. 
Beazley, H. (2000) 'Home sweet home? Street children's sites of belonging', in S. Holloway and G. Valentine (eds) Children's geographies: playing, living, learning, London: Routledge, 194-212.

Boccagni, P. (2012) 'Practising motherhood at a distance: retention and loss in Ecuadorian transnational families', Journal of Ethnic and Migration Studies, 38 (2), 261-77, doi: 10.1080/1369183X.2012.646421.

Camacho, A. Z. V. (1999) 'Family, child labour and migration: child domestic workers in Metro Manila', Childhood, 6 (1), 57-73, doi: 10.1177/0907568299006001005.

Carling, J. (2008) 'The human dynamics of migrant transnationalism', Ethnic and Racial Studies, 31 (8), 1452-77, doi: 10.1080/01419870701719097.

Carling, J., C. Menjívar and L. Schmalzbauer (2012) 'Central themes in the study of transnational parenthood', Journal of Ethnic and Migration Studies, 38 (2), 191-217, doi: $10.1080 / 1369183$ X.2012.646417.

Cresswell, T. (2010) 'Towards a politics of mobility', Environment and Planning D: Society and Space, 28 (1), 17-31, doi:10.1068/d11407.

Dang, N. A., T. B. Tran, N. Q. Nguyen and T. S. Dao (2010) Development on the move: measuring and optimising migration's economic and social impacts in Vietnam, Hanoi: Global Development Network/Institute for Public Policy Research.

di Leonardo, M. (1987) 'The female world of cards and holidays: women, families, and the work of kinship', Signs, 12 (3), 440-53, avialable at: www.jstor.org/stable/3174331.

Dobson, M. E. (2009) 'Unpacking children in migration research', Children's Geographies, 7 (3), 355-60, doi: 10.1080/14733280903024514.

Douglass, M. (2006) 'Global householding in Pacific Asia', International Development Planning Review, 28 (4), 421-46, doi: 10.3828/idpr.28.4.1.

Dreby, J. (2006) 'Honor and virtue: Mexican parenting in the transnational context', Gender and Society, 20 (1), 32-59, doi:10.1177/0891243205282660.

Dreby, J. (2007) 'Children and power in Mexican transnational families', Journal of Marriage and Family, 69 (4), 1050-64, doi: 10.1111/j.1741-3737.2007.00430.x.

Dreby, J. (2010) Divided by borders: Mexican migrants and their children, Berkeley: University of California Press.

Eisenberg, N., R. A. Fabes and B. C. Murphy (1995) 'Relations of shyness and low sociability to regulation and emotionality', Journal of Personality and Social Psychology, 68 (3), 505-17, doi: 10.1037/0022-3514.68.3.505.

Ennew, J., W. Myers and D. P. Plateau (2005) 'Defining child labor as if human rights really matter', in B. Weston (ed.) Child labor and human rights: making children matter, Boulder, CO: Lynne Rienner, 27-54.

Fedyuk, O. (2012) 'Images of transnational motherhood: the role of photographs in measuring time and maintaining connections between Ukraine and Italy', Journal of Ethnic and Migration Studies, 38 (2), 279-300, doi: 10.1080/1369183X.2012.646422.

Hoang, L. A. and B. Yeoh (2012) 'Sustaining families across transnational spaces: Vietnamese migrant parents and their left-behind children', Asian Studies Review, 36 (3), 307-27, doi: 10.1080/10357823.2012.711810.

Hoang, L. A., T. Lam, B. S. A. Yeoh and E. Graham (forthcoming) Transnational labour migration and changing care arrangements for left-behind children in Southeast Asia, Children's Geographies, journal articles are available at: www.tandfonline.com/loi/ cchg20\#.U3NjeCjm-z4.

Iversen, V. (2002) 'Autonomy in child labor migrants', World Development, 30 (5), 817-34, doi: 10.1016/S0305-750X(02)00007-4.

James, A. and A. Prout (1997) Constructing and reconstructing childhood: contemporary issues in the sociological study of childhood, Basingstoke: Falmer Press.

James, A., C. Jenks and A. Prout (1998) Theorizing childhood, Oxford: Polity Press.

Jenks, C. (1996) Childhood, London: Routledge. 
Katz, C. (2004) Growing up global: economic restructuring and children's everyday lives Minneapolis: University of Minnesota Press.

Langevang, T. and K. V. Gough (2009) 'Surviving through movement: the mobility of urban youth in Ghana', Social \& Cultural Geography, 10 (7), 741-56, doi: 10.1080/1464936090 3205116.

Lansdown, G. (1994) 'Children's rights', in B. Mayall (ed.) Children's childhoods: observed and experienced, London: Falmer Press, 33-44.

Leifsen, E. and A. Tymczuk (2012) 'Care at a distance: Ukrainian and Ecuadorian transnational parenthood from Spain', Journal of Ethnic and Migration Studies, 38 (2), 219-36, doi: 10.1080/1369183X.2012.646419.

McCarthy, A. and K. Lee (2009) 'Children's knowledge of deceptive gaze cues and its relation to their actual lying behavior', Journal of Experimental Psychology, 103 (2), 117-34, doi: 10.1016/j.jecp.2008.06.005.

Mahler, S. J. (2001) 'Transnational relationships: the struggle to communicate across borders', Identities: Global Studies in Culture and Power, 7 (4), 583-619, doi: 10.1080/ 1070289X.2001.9962679.

Margold, J. (2004) 'Filipina depictions of migrant life for those at home', in L. D. Long and E. Oxfeld (eds) Coming home? Refugees, migrants, and those who stayed behind, Philadelphia: University of Pennsylvania Press, 49-62.

Matilac, R. and R. Florendo (2002) Child trafficking in Southeast Asia, Manila: International Campaign Against Child Trafficking.

Menjivar, C. (2000) Fragmented ties: Salvadoran immigrant networks in America, Los Angeles: University of California Press.

Moran-Taylor, M. (2008) 'When mothers and fathers migrate north: caretakers, children, and child rearing in Guatemala', Latin American Perspectives, 35 (4), 79-95, doi: 10.1177/ 0094582 X08318980.

Morrow, V. (2008) 'Ethical dilemmas in research with children and young people about their social environments', Children's Geographies, 6 (1), 49-61, doi: 10.1080/1473328070 1791918.

Ní Laoire, C., F. Carpena-Méndez, N. Tyrrell and A. White (2010) 'Introduction: childhood and migration - mobilities, homes and belongings', Childhood, 17 (2), 155-62, doi: $10.1177 / 0907568210365463$.

Nieuwenhuys, O. (1994) Children's lifeworlds: gender, welfare, and labour in the developing world, London: Routledge.

O'Connell Davidson, J. (2005) Children in the global sex trade, Cambridge: Polity.

Olwig, K. F. (1999) 'Narratives of the children left behind: home and identity in globalised Caribbean families', Journal of Ethnic and Migration Studies, 25 (2), 267-84, doi: 10.1080/ 1369183X.1999.9976685.

Orellana, M. F., B. Thorne, A. Chee and W. S. E. Lam (2001) 'Transnational childhoods: the participation of children in processes of family migration', Social Problems, 48 (4), 572-91, doi: 10.1525/sp.2001.48.4.572.

Parreñas, R. S. (2001) 'Mothering from a distance: emotions, gender and inter-generational relations in Filipino transnational families', Feminist Studies, 27 (2), 361-90.

Parreñas, R. S. (2005a) 'Long distance intimacy: class, gender and intergenerational relations between mothers and children in Filipino transnational families', Global Networks, 5 (4), 317-36, doi: 10.1111/j.1471-0374.2005.00122.x.

Parreñas, R. S.(2005b) Children of global migration: transnational families and gendered woes, Stanford: Stanford University Press.

Parreñas, R. S. (2008) 'Transnational fathering: gendered conflicts, distant disciplining and emotional gaps', Journal of Ethnic and Migration Studies, 34 (7), 1057-72, doi: 10.1080/ 13691830802230356.

Pertierra, R. (2006) Transforming technologies: altered selves, Manila: DLSU Press. 
Pribilsky, J. (2004) “"Aprendemos a convivir”: conjugal relations, co-parenting and family life among Ecuadorian transnational migrants in New York City and the Ecuadorian Andes', Global Networks, 4 (3), 313-24, doi: 10.1111/j.1471-0374.2004.00096.x.

Punch, S. (2002) 'Youth transitions and interdependent adult-child relations in rural Bolivia', Journal of Rural Studies, 18 (2), 123-33, doi: 10.1016/S0743-0167(01)00034-1.

Punch, S. (2007) 'Negotiating migrant identities: young people in Bolivia and Argentina', Children's Geographies, 5 (1), 95-112, doi: 10.1080/14733280601108213.

Ramirez, M., Z. Skribis and M. Emmison (2007) 'Transnational family reunions as lived experience: narrating a Salvadorian autoethnography', Identities, 14 (4), 411-31, doi: 10.1080/10702890701578456.

Salazar, N. B. (2010) 'Tanzanian migration imaginaries', International Migration Institute working paper no 20, available at: www.imi.ox.ac.uk/pdfs/wp20-salazar-1.

Sanders, T. (2001) 'Territorial and magical migrations in Tanzania', in M. de Bruijn, R. van Dijk and D. Foeken (eds) Mobile Africa: changing patterns of movement in Africa and beyond, Leiden: Brill, 27-46.

Schmalzbauer, L. (2004) 'Searching for wages and mothering from afar: the case of Honduran transnational families', Journal of Marriage and Family, 66 (5), 1317-31, doi: 10.1111/j.0022-2445.2004.00095.x.

Schmalzbauer, L. (2008) 'Family divided: the class formation of Honduran transnational families', Global Networks, 8 (3), 329-46, doi: 10.1111/j.1471-0374.2008.00198.x.

Sheller, M. and J. Urry (2006) 'The new mobilities paradigm', Environment and Planning A, 38 (2), 207-26, doi: 10.1068/a37268.

Taylor, C. (2002) 'Modern social imaginaries', Public Culture, 14 (1), 91-124, doi: 10.1215/ 08992363-14-1-91.

Trask, B. S. (2010) Globalization and families: accelerated systemic social change, New York: Springer.

Uprichard, E. (2008) "Children as "being and becomings": children, childhood and temporality', Children \& Society, 22 (4), 303-13, doi: 10.1111/j.1099-0860.2007.00110.x.

Vertovec, S. (2004) 'Cheap calls: the social glue of migrant transnationalism', Global Networks, 4 (2), 219-24, doi: 10.1111/j.1471-0374.2004.00088.x.

Vigh, H. E. (2006) Navigating terrains of war: youth and soldiering in Guinea-Bissau, New York: Berghahn Books.

Whitehead, A., I. H. Hashim and V. Iversen (2007) 'Child migration, child agency and intergenerational relations in Africa and South Asia', working paper T24, Brighton: Development Research Centre on Migration, Globalisation and Poverty, available at: http://r4d.dfid.gov.uk/PDF/Outputs/MigrationGlobPov/WP-T24.pdf.

Zentgraf, K. M. and N. S. Chinchilla (2012) 'Transnational family separation: a framework for analysis', Journal of Ethnic and Migration Studies, 38 (2), 345-66, doi: 10.1080/ 1369183X.2011.646431. 


\section{University Library}

\section{- M M I N E R VA A gateway to Melbourne's research publications}

Minerva Access is the Institutional Repository of The University of Melbourne

Author/s:

Hoang, LA;YEOH, BRENDASA

Title:

Children's agency and its contradictions in the context of transnational labour migration from Vietnam

Date:

2015-04-01

Citation:

Hoang, L. A. \& YEOH, B. R. E. N. D. A. S. A. (2015). Children's agency and its contradictions in the context of transnational labour migration from Vietnam. Global Networks, 15 (2), pp.180-197. https://doi.org/10.1111/glob.12057.

Persistent Link:

http://hdl.handle.net/11343/51227 